\title{
LAND SNAIL FAUNA OF THE MEKONG DELTA LIMESTONE HILLS (CAMBODIA, VIETNAM): NOTHARINIA VERMEULEN, PHUNG ET TRUONG, 2007, AND A NOTE ON PLECTOSTOMA A. ADAMS, 1865 (MOLLUSCA: GASTROPODA: CAENOGASTROPODA: DIPLOMMATINIDAE)
}

\author{
JaAP J. Vermeulen ${ }^{1 *}$, Hong TRUONG LUU ${ }^{2}$, KeUm Theary ${ }^{3}$, Katie AnKer ${ }^{1}$
}

${ }^{1} \mathrm{JK}$ art and science, Lauwerbes 82318 AT Leiden, Netherlands (e-mail: jk.artandscience@gmail.com) ${ }^{2}$ Southern Institute of Ecology, Vietnam Academy of Science and Technology, 1 Mac Dinh Chi Street, Ho Chi Minh City, Vietnam (e-mail: hongtruongluu@gmail.com)

${ }^{3}$ Cambodian Entomology Initiatives, Royal University of Phnom Penh, Phnom Penh 12101 Cambodia (e-mail: thearykeum97@gmail.com)

*corresponding author

ABSTRACT: Seven new species of Notharinia Vermeulen, Phung et Truong, 2007 (Mollusca, Gastropoda, Diplommatinidae; formerly included in Pupinidae) are described from limestone hills on the east flank of the Mekong Delta, in Vietnam and Cambodia. A map showing the distribution of all ten species now known from the area is presented. In addition, Plectostoma haplohelix Vermeulen, Luu, Keum et Anker, 2019, is synonymised with P. lavillei (Dautzenberg et Fischer, 1905).

KEY WORDS: land snails, Notharinia, Plectostoma, Cambodia, Vietnam, Mekong Delta Limestone Hills

\section{INTRODUCTION}

This paper presents a revision of the genus Notharinia Vermeulen, Phung et Truong, 2007 with ten endemic species in the Mekong Delta Limestones (MDL), a string of limestone hills in Vietnam and Cambodia, on the west flank of the Mekong river delta (see VERMEULEN et al. 2019: fig. 1). Seven species are new to science.

\section{TAXONOMY}

VERMEULEN et al. (2007) included Notharinia, a genus of overall diplommatinid appearance, in the Pupinidae because the three species known at that time did not have a constriction in the spire, which is characteristic of Diplommatinidae (VERMEULEN
VERMEULEN et al. (2019) illustrate the degradation of the MDL biodiversity by habitat loss. The fate of selected species is recorded in proposals for inclusion in the IUCN RED LIST. In these proposals, informal names are used for new species described in the present paper; these informal names are listed with the proposed IUCN Red List Category for each species.
1996: 90). Since then, more species have come to light: Arinia (Notharinia) boucheti Pall-Gergely et Hunyadi, 2018, from Laos (PÁlL-GERGELY \& HUNYADI 2018), and seven new, described below. Two, $N$. constricta sp. $\mathrm{n}$. and $N$. ongensis sp. n., do have a constriction in the 
spire, albeit one without a circular ridge in the narrowest part, and without internal lamellae which are often present in the Diplommatinidae. This supports the transfer of Notharinia to the Diplommatinidae, as proposed by EGOROV (2013). The transfer, however, considerably stretches the diagnostic set of characters for the family by inclusion of a suite of species without a trace of a constriction in the spire.

Two more species from Peninsular Malaysia (Notharinia linnei Maassen, 2008, and Arinia (Notharinia) micro Marzuki et Foon, 2016), differ in having a spiral sculpture (absent in other Notharinia) and may be of different affinity (MAASSEN 2008, MARZUKI \& FOON 2016).

EGOROV (2013) also subsumes Notharinia under the genus Arinia H. et A. Adams, 1856 (ADAMS \& ADAMS 1854-1858), a genus with numerous species in Borneo, the Philippines, and the Sunda Islands (see VERMEULEN 1996, for the Borneo species). We retain Notharinia at generic level with the circular thickening in the constriction, present in Arinia (see Vermeulen 1996: 92), absent in Notharinia as distinguishing feature. In general, the division of Diplommatinidae into genera contains many uncertainties, and needs revision.

\section{MATERIAL AND METHODS}

The material studied derives from the private collection of the first author (' $\mathrm{V}$ ' in the lists of examined material below). Type specimens are stored in NHMUK (Natural History Museum, London, United Kingdom) and RMNH (National Museum of Natural History, formerly Rijksmuseum van Natuurlijke Historie, Leiden, the Netherlands). Duplicate sets of the cited material will be stored in institutes in Vietnam and Cambodia. The illustrations were

drawn by the first author, with the aid of a Wild M8 stereo microscope with a Camera Lucida device. The first author claims copyright of the illustrations of the snail species.

The toponymy of the area is still unsettled. We have used names of hills as in VERMEULEN et al. (2019: table 1). There, coordinates are given for each hill. In the etymology section, two abbreviations are used 'Gr' for Ancient Greek, 'L' for Latin.

\section{SYSTEMATIC PART}

\section{Family Diplommatinidae L. Pfeiffer, 1857}

\section{Genus Notharinia Vermeulen, Phung et Truong, 2007}

\section{KEY TO THE SPECIES OF THE MEKONG DELTA LIMESTONE HILLS}

1 - Umbilical area distinctly concave. Coiling axis (almost) visible in umbilical view, or in slightly oblique view ............. Group 1 (page II)

1a - Umbilical area not or hardly concave. Coiling axis not visible in umbilical or in slightly oblique view, covered by the last half-whorl ..... go to 2

2 - Aperture free: Parietal side distant from the previous whorl ............. Group 2 (page V)

$2 \mathrm{a}$ - Aperture on the parietal side attached to the previous whorl ................. go to 3

3 - Peristome simple ........ Group 3 (page VII)

3a - Peristome double, sometimes indistinctly so...

...................... go to 4

4 - Inner peristome slightly protruding from the outer (Figs 17, 19) .......... Group 4 (page VII)

$4 \mathrm{a}$ - Inner peristome distinctly protruding from the outer (Figs 21, 23) ....... Group 5 (page IX)

\section{Group 1}

\section{Notharinia brevior Vermeulen, Phung et Truong, 2007}

Figs 1 (dark blue dots), 2-3

VERMEULEN et al. 2007: 85.

Examined material. Cambodia: Kampot Province, Banteay Meas area: Phnom Koun Sat (V 15668/5 shells); Kampot area: Phnom Kbal Romeas (V 15670/1). Vietnam: Kien Giang Province, Ha Tien Town area: Nui Da Dung (V 15048/2); Nui Thach Dong (holotype: RMNH 108983, paratypes: V 11468/>10).

Description. Shell minute, white. Spire shortly cylindrical to somewhat ovoid-cylindrical, towards the apex widely rounded to somewhat truncated. Apex slightly oblique. Whorls convex, the last $11 / 2$ whorl often only moderately convex; suture impressed. Constriction absent. Sculpture. Radial ribs straight, distinct, rather low and thin, (very) densely spaced, $16-28$ ribs/ $0.5 \mathrm{~mm}$ on the first part of penultimate whorl; radial ribs on the body whorl 11-18/0.5 mm above the aperture, usually somewhat wider spaced, at least not congested, towards the peristome. Spiral 


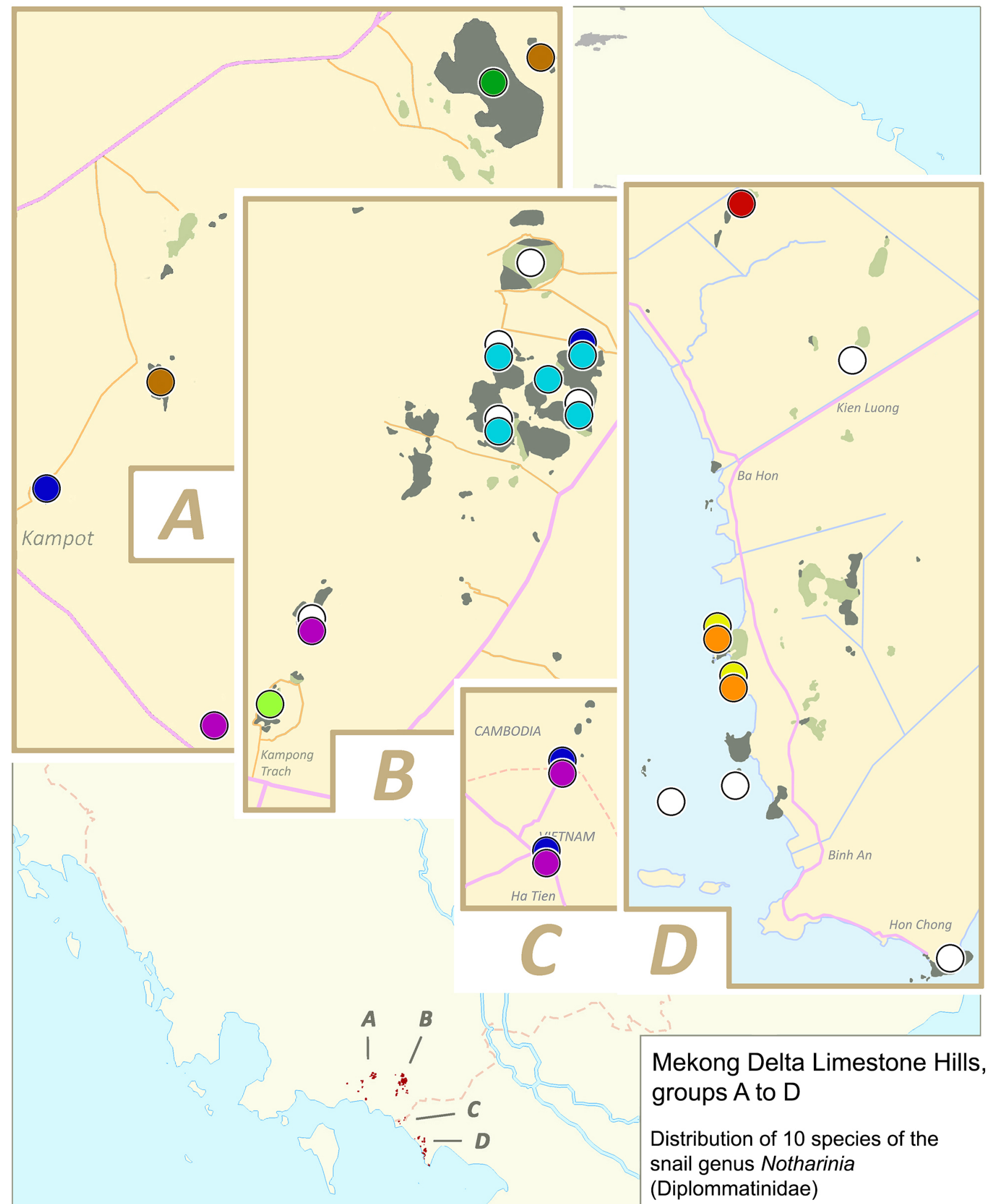

Overlapping dots: sympatric species

Fig. 1. Distribution of Notharinia species in the Mekong Delta Limestones. Dots of different colours represent different species: white $-N$. attenuata; yellow $-N$. subduplex sp. n.; orange $-N$. whitteni sp. n.; red $-N$. ongensis sp. n.; brown $-N$. constricta sp. n.; purple $-N$. crassilabris; dark blue $-N$. brevior; light blue $-N$. soluta sp. n.; light green $-N$. lyostoma sp. n.; dark green - N. stenobasis sp. n. 
striation absent. Aperture attached to penultimate whorl over a short distance only, approx. circular; spire slightly expanded towards the aperture. Peristome simple, sometimes inconspicuously double because of a radial rib very close to the margin, approx. equally wide all around the aperture, somewhat thickened and somewhat reflexed. Umbilicus closed, body whorl loosely coiled so that the coiling axis is visible, umbilical area distinctly concave.

Dimensions. Height 1.45-1.60 mm; width (body whorl excluded) $0.75-0.90 \mathrm{~mm}$; height/width $1.61-$ 2.00; number of whorls $41 / 8-41 / 2$; aperture height $0.50-0.55 \mathrm{~mm}$; width $0.50-0.65 \mathrm{~mm}$.

Ecology. Soil deposits in degraded secondary woodland on limestone bedrock.

Distribution. Cambodia, Kampot Province, Kampot area, Banteay Meas area. Vietnam, Kien Giang Province, Ha Tien Town area. Presumably endemic to the MDL.
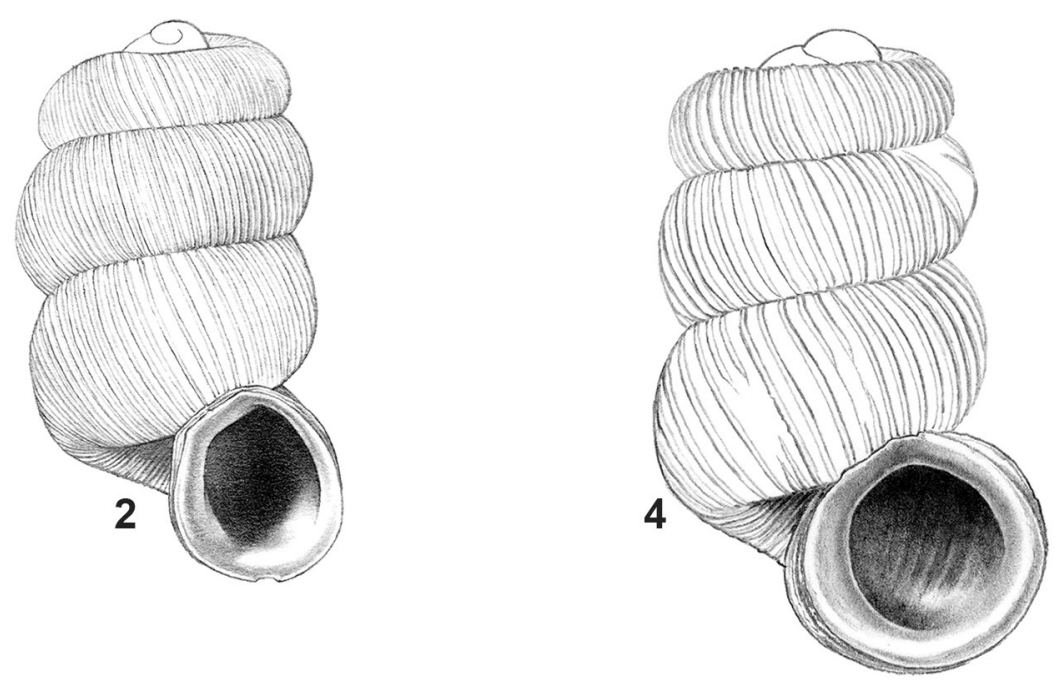

Variation. On average, Vietnam specimens (including the type) have the radial ribs more densely placed than the specimens from Cambodia.

\section{Notharinia constricta sp. $\mathrm{n}$.}

Figs 1 (brown dots), $4-5$

Examined material. Cambodia: Kampot Province, Kampot area: Phnom Chhngauk (Holotype: NHMUK 20180554, paratypes: V 15669/>10 shells); Phnom La'Ang, northernmost satellite limestone outcrop along east side of hill (V 17081/3).

Cross diagnosis. Most similar to N. brevior, differs in having a distinctly double peristome. Additionally, the radial ribs are less densely spaced (9-12 ribs/0.5 $\mathrm{mm}$ on the first part of penultimate whorl, versus $16-28$ ribs $/ 0.5 \mathrm{~mm}$ ).
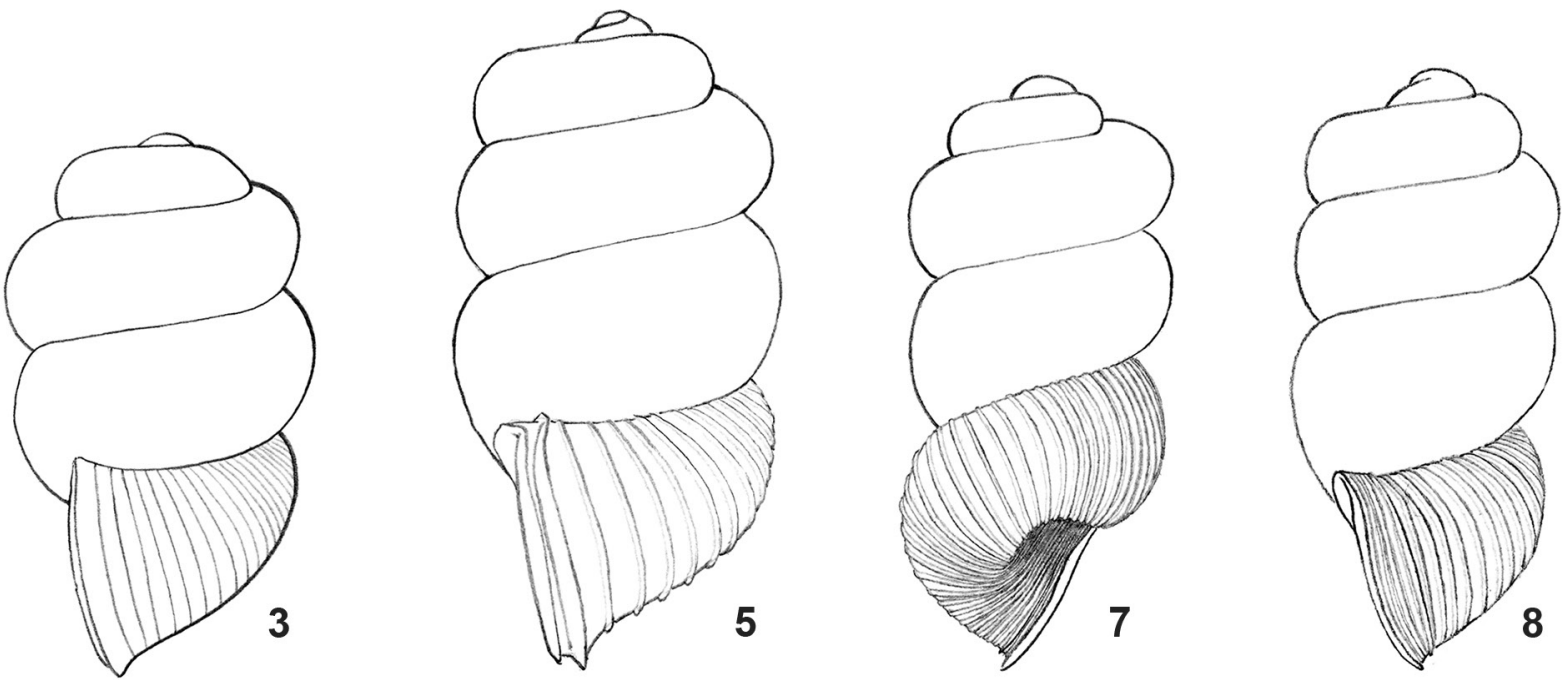

Figs 2-8. Notharinia brevior Vermeulen, Phung et Truong: 2 - holotype, frontal view, shell height $1.7 \mathrm{~mm}, 3$ - same, right lateral view; Notharinia constricta sp. n.: 4 - holotype, frontal view, shell height $1.8 \mathrm{~mm}, 5$ - same, right lateral view; Notharinia ongensis sp. n.: 6 - holotype, frontal view, shell height $1.5 \mathrm{~mm}, 7$ - same, right lateral view, 8 - same, left lateral view 
Description. Shell minute, white. Spire (rather) shortly cylindrical, rarely slightly ellipsoid, towards the apex widely rounded to truncated. Apex slightly oblique. Whorls convex, the body whorl rarely moderately convex; suture impressed. Constriction absent, or in some specimens a slight narrowing of the spire approx. 1/2 whorl before the aperture. Internal lamellae absent. Sculpture. Radial ribs straight, distinct, rather low and thin, (rather) densely spaced, 9-12 ribs $/ 0.5 \mathrm{~mm}$ on the first part of penultimate whorl; radial ribs on the body whorl $6-11 / 0.5 \mathrm{~mm}$ above the aperture, usually (somewhat) wider spaced, at least not congested, towards the peristome. Spiral striation absent. Aperture attached to the penultimate whorl over a short distance only, approx. circular; spire slightly expanded towards the aperture. Peristome double; outer peristome slightly to moderately expanding beyond the inner on the upper palatal side and in the basal corner; inner peristome slightly to distinctly protruding from the outer, with a few coarse lamellae to numerous fine lamellae on the outer surface, approx. equally wide all around the aperture, somewhat thickened and somewhat reflexed. Umbilicus closed, body whorl loosely coiled so that the coiling axis is (almost) visible, umbilical area distinctly concave.

Dimensions. Height $1.45-1.80 \mathrm{~mm}$; width (body whorl excluded) $0.80-0.90 \mathrm{~mm}$; height/width $1.76-$ 2.25; number of whorls $41 / 8-43 / 4$; aperture height 0.50-0.65 mm; width $0.60-0.70 \mathrm{~mm}$.

Ecology. Soil deposits in moderately disturbed to degraded partly deciduous woodland on limestone bedrock.

Distribution. Cambodia, Kampot Province, Kampot area. Presumably endemic to the Cambodian part of the MDL.

Etymology. Constringere (L) - to bind tight, to confine

\section{Notharinia ongensis sp. $\mathrm{n}$.}

Figs 1 (red dot), 6-8

IUCN RED LIST Category, as Notharinia sp. nov. 'Khoe La \& Ong': Critically Endangered Blab(i,ii,iii,iv,v) $+2 \mathrm{ab}(\mathrm{i}, \mathrm{ii}, \mathrm{iii}, \mathrm{iv}, \mathrm{v})$. Should be re-assessed because of present changes in species delimitation: it was assessed together with what we here describe as $N$. whitteni sp. n. See also note below.

Examined material. Vietnam: Kien Giang Province, Kien Luong District: Nui Ong (Holotype: NHMUK 20180555, paratypes: V 14682/4 shells).

Cross diagnosis. Differs from N. brevior and N. constricta sp. $\mathrm{n}$. in having a narrower spire. Besides, it differs from the first in having a constriction $1 / 2$ whorl from the aperture, and from the second in its simple peristome. Also, $N$. ongensis often has its peristome more distinctly expanded on the columellar side than other MDL Notharinia species.
Description. Shell minute, white. Spire rather shortly cylindrical, towards the apex widely rounded. Apex slightly oblique. Whorls (moderately) convex; suture impressed. Constriction as a slight to moderately distinct narrowing of the spire approx. $1 / 2$ whorl before the aperture. Internal lamellae absent (observed through shell wall only). Sculpture. Radial ribs straight, distinct, rather low and thin, (very) densely spaced, 13-22 ribs/0.5 $\mathrm{mm}$ on the first part of penultimate whorl; radial ribs on the body whorl 12-16/0.5 $\mathrm{mm}$ above the aperture, usually (somewhat) wider spaced towards the peristome, but in some specimens with many fine, densely placed lamellae close to the peristome. Spiral striation absent. Aperture attached to the penultimate whorl over a short distance only, approx. circular; spire slightly expanded towards the aperture. Peristome simple, slightly expanding along the upper palatal side or not, slightly to distinctly expanding in the basal corner and on the columellar side. Umbilicus closed, body whorl loosely coiled so that the coiling axis is visible in oblique view, umbilical area distinctly concave.

Dimensions. Height 1.35-1.50 mm; width (last whorl excluded) $0.65-0.70 \mathrm{~mm}$; height/width 1.93 2.31; number of whorls $41 / 4-41 / 2$; aperture height $0.40-0.45 \mathrm{~mm}$; width $0.45-0.55 \mathrm{~mm}$.

Ecology. Soil deposits in disturbed to degraded woodland on limestone bedrock.

Distribution. Vietnam, Kien Giang Province, Kien Luong Dist., Nui Ong. Presumably a site endemic species.

Etymology. Named after the type locality.

\section{Group 2}

\section{Notharinia lyostoma sp. $\mathrm{n}$.}

Figs 1 (light green dot), 9-10

Examined material. Cambodia: Kampot Province, Kampong Trach area: Phnom Kampong Trach (holotype: NHMUK 20180556, paratypes: V 15676/>10 shells).

Cross diagnosis. Characterised within the genus by the free aperture combined with the densely spaced radial ribs.

Description. Shell minute, white. Spire cylindrical, usually slightly attenuated towards the basis, widely rounded to truncated towards the apex. Apex slightly oblique. Whorls convex, approx. one whorl half-way the spire somewhat less convex in some shells; suture impressed. Constriction absent. Sculpture. Radial ribs on the upper whorls straight, distinct, rather low and thin, densely spaced, $9-17 / 0.5 \mathrm{~mm}$ on the first part of penultimate whorl, 9-15/0.5 $\mathrm{mm}$ above the aperture, usually somewhat wider spaced towards the peristome and with one or a few more prominent ones 
at irregular intervals, sometimes with a few lamellae close together forming a thickened rim just behind the peristome. Spiral striation absent. Aperture free, with the parietal edge distant from the penultimate whorl, approx. circular; spire often slightly expanded towards the aperture. Peristome simple, approx. equally wide all around the aperture, somewhat thickened and somewhat reflexed. Umbilicus closed, covered by the body whorl in umbilical view.
Dimensions. Height $1.85-2.35 \mathrm{~mm}$; width (last whorl excluded) $0.80-0.95 \mathrm{~mm}$; height/width 2.18 2.63; number of whorls 5-5 3/4; aperture height $0.50-0.70 \mathrm{~mm}$; width $0.50-0.60 \mathrm{~mm}$.

Ecology. Soil deposits in degraded woodland on limestone bedrock.

Distribution. Cambodia, Kampot Province, Phnom Kampong Trach. Presumably a site endemic species.

Etymology. luein $(\mathrm{Gr})$ to loosen anything bound, stoma (Gr) mouth
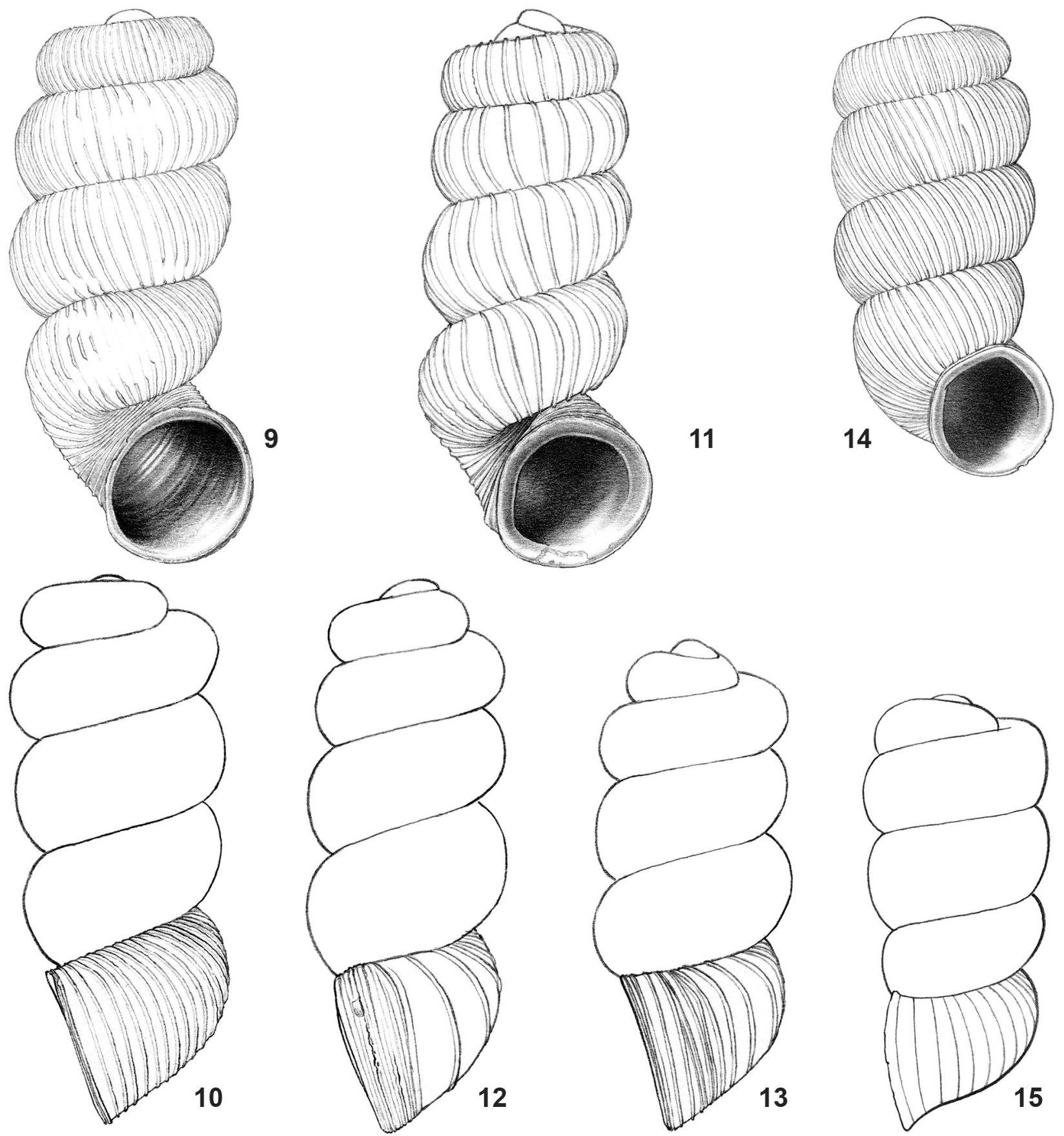

Figs 9-15. Notharinia lyostoma sp. n.: 9 - holotype, frontal view, shell height $2.3 \mathrm{~mm}, 10$ - same, right lateral view; Notharinia soluta sp. n.: 11 - holotype, frontal view, shell height $2.1 \mathrm{~mm}, 12$ - same, right lateral view, 13 - paratype (V 15681), right lateral view; Notharinia attenuata Vermeulen, Phung et Truong: 14 - holotype, frontal view, shell height $2.0 \mathrm{~mm}, 15$ - same, right lateral view 


\section{Notharinia soluta sp. $\mathrm{n}$.}

Figs 1 (light blue dots), 11-13

Examined material. Cambodia: Kampot Province, Banteay Meas area: nameless small limestone hill (V 15683/1 shell); Phnom Koun Sat (holotype: NHMUK 20180557, paratypes: V 15681/6); Phnom Kunea Luong, east hill (V 15682/2); Phnom Teuk Srok, north hill (V 15679/3); same, south hill (V 15680/1). Cross diagnosis. Differs from N. lyostoma sp. n. in the strictly cylindrical spire, which is not attenuated towards the aperture, and in the more widely spaced radial ribs.

Description. Shell minute, white. Spire cylindri$\mathrm{cal}$, not attenuated towards the basis, towards the apex rounded to truncated. Apex slightly oblique. Whorls convex, suture impressed. Constriction absent. Sculpture. Radial ribs on the upper whorls straight, distinct, rather low and thin, moderately spaced, $5-8 / 0.5 \mathrm{~mm}$ on the first part of penultimate whorl, 4-7/0.5 $\mathrm{mm}$ above the aperture, usually widely spaced towards the peristome, but often more densely arranged, or with numerous fine lamellae at regular or irregular intervals near the aperture. Spiral striation absent. Aperture free, with the parietal edge distant from the previous whorl, approx. circular but often slightly angular in the basal corner; spire slightly expanded towards the aperture. Peristome simple, approx. equally wide all around the aperture but often slightly wider in the basal corner, somewhat thickened and somewhat reflexed. Umbilicus closed, covered by the body whorl in umbilical view. Dimensions. Height 1.90-2.30 mm; width (last whorl excluded) $0.75-0.90 \mathrm{~mm}$; height/width 2.28 2.75; number of whorls $43 / 4-51 / 2$; aperture height 0.60-0.70 mm; width $0.60-0.70 \mathrm{~mm}$.

Ecology. Soil deposits in degraded woodland on limestone bedrock.

Distribution. Cambodia, Kampot Province, Banteay Meas area. Presumably endemic to the Cambodian part of the MDL.

Etymology. solutus (L) - free, unbound

\section{Group 3}

\section{Notharinia attenuata Vermeulen, Phung et Truong, 2007}

Figs 1 (white dots), 14-15

VERMEULEN et al. 2007: 85.

Examined material. Cambodia: Kampot Province, Banteay Meas area: Phnom Kunea Luong, east hill (V 15674/4 shells); Phnom Teuk Srok, north hill (V 15672/>10); same, south hill (V 15673/1); Phnom Totung (V 15671/1); Kampong Trach area: Phnom
Damrey, south hill (V 15675/1). Vietnam: Kien Giang Province, Kien Luong District: Nui Chau Hang (V 14683/>10); Hon Da Lua, east group, the middle (largest) island, west side (V 15050/>10); Hon Lo Coc (V 15051/1); Nui Chua Hang (= Pagoda Hill), north flank of hill and west end, slopes bordering temple complex (holotype: RMNH 108981, paratypes: V 9993/10); same, southeast end of hill, steep sea-facing slope (V 15046/1 \& V 15047/3); same, Hang Gieng Tien, cave in south facing cliff of hill, bordering the sea (V 15049/3).

Cross diagnosis. Specimens of N. subduplex sp. n. with an indistinctly double peristome differ from $N$. attenuata in the wider shell.

Description. Shell minute, white. Spire cylindrical but often somewhat attenuated towards the basis, towards the apex widely rounded to somewhat truncated. Apex slightly oblique. Whorls convex, 1-1 $1 / 2$ whorl half-way the spire sometimes only moderately convex; suture impressed. Constriction absent. Sculpture. Radial ribs on the upper whorls straight, distinct, rather low and thin, densely placed, 10-18 ribs $/ 0.5 \mathrm{~mm}$ on the first part of the penultimate whorl; radial ribs on the last whorl approx. straight or slightly sinuous, particularly towards the suture and the umbilicus, $10-14$ ribs $/ 0.5 \mathrm{~mm}$ above the aperture, usually somewhat wider spaced, at least not congested, towards the peristome. Spiral striation absent. Aperture attached to the penultimate whorl, approx. circular; spire slightly expanded towards the aperture. Peristome simple, approx. equally wide all around the aperture, somewhat thickened and somewhat reflexed. Umbilicus closed, covered by the last whorl which is so tightly coiled that hardly an umbilical impression is left.

Dimensions. Height $1.55-2.30 \mathrm{~mm}$; width (last whorl excluded) $0.65-0.95 \mathrm{~mm}$; height/width 2.12 2.69; number of whorls 4 7/8-5 5/8; aperture height $0.45-0.70 \mathrm{~mm}$; width $0.50-0.60 \mathrm{~mm}$.

Ecology. Soil deposits in somewhat disturbed to degraded semi-deciduous woodland on limestone bedrock.

Distribution. Cambodia, Kampot Province, Banteay Meas area, Kampong Trach area. Vietnam, Kien Giang Province, Kien Luong District. Presumably endemic to the MDL.

\section{Group 4}

\section{Notharinia stenobasis sp. $\mathrm{n}$.}

Figs 1 (dark green dot), 16-17

Examined material. Cambodia: Kampot Province, Kampot area: Phnom La'Ang, southeast-end (holotype: NHMUK 20180558, paratypes: V 17080/>10 shells). 
Cross diagnosis. Differs from N. subduplex sp. n. in the narrower spire which is attenuated towards the aperture.

Description. Shell minute, white. Spire cylindrical, slightly to distinctly attenuated towards the basis, towards the apex (almost) truncated. Apex slightly oblique. Whorls convex; suture impressed. Constriction absent. Sculpture. Radial ribs straight, distinct, rather low and thin, (rather) densely spaced, $10-13 / 0.5 \mathrm{~mm}$ on the first part of penultimate whorl; radial ribs on the body whorl curved towards the suture, (rather) densely spaced, $9-13$ ribs $/ 0.5 \mathrm{~mm}$
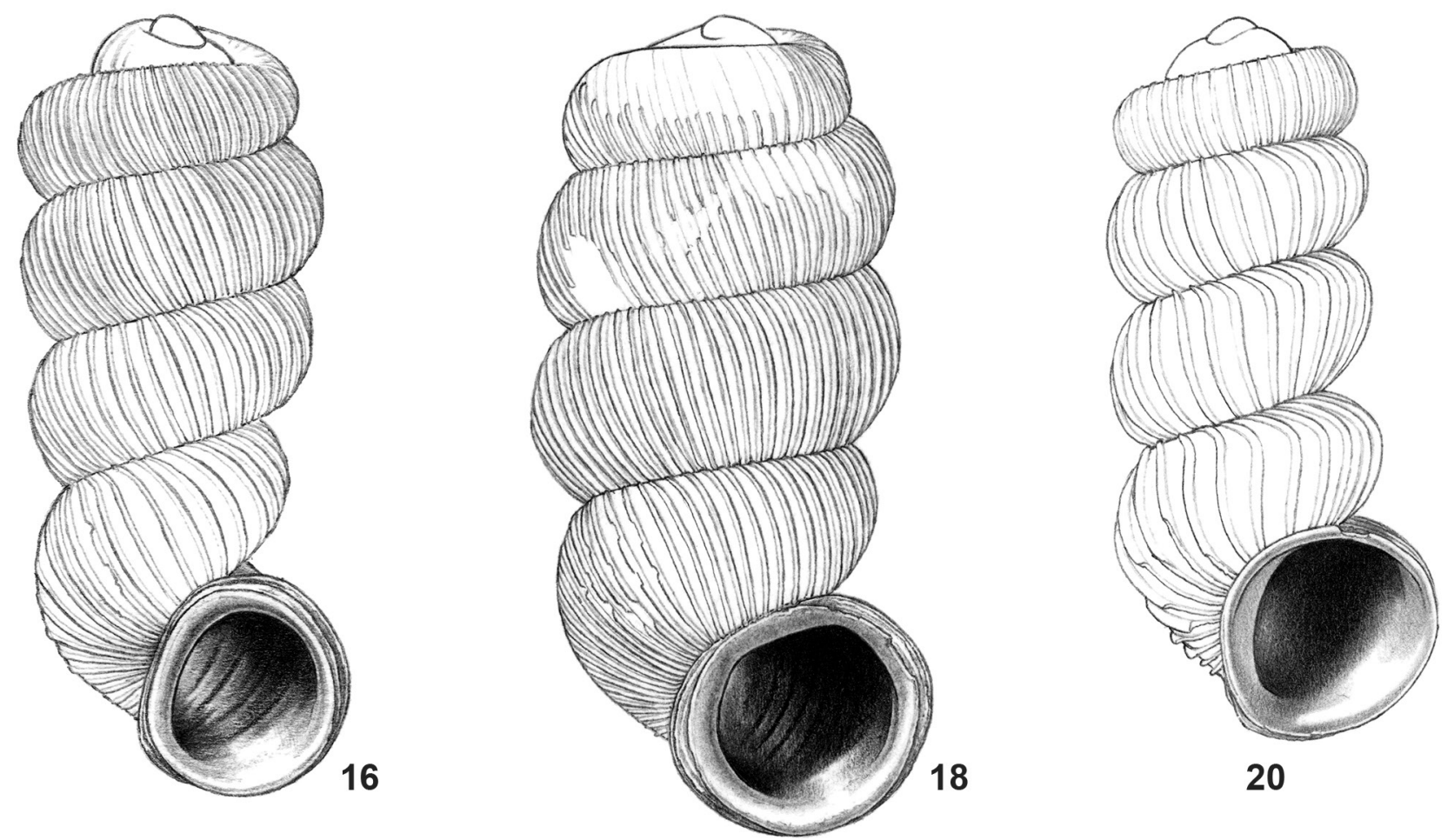

18

20
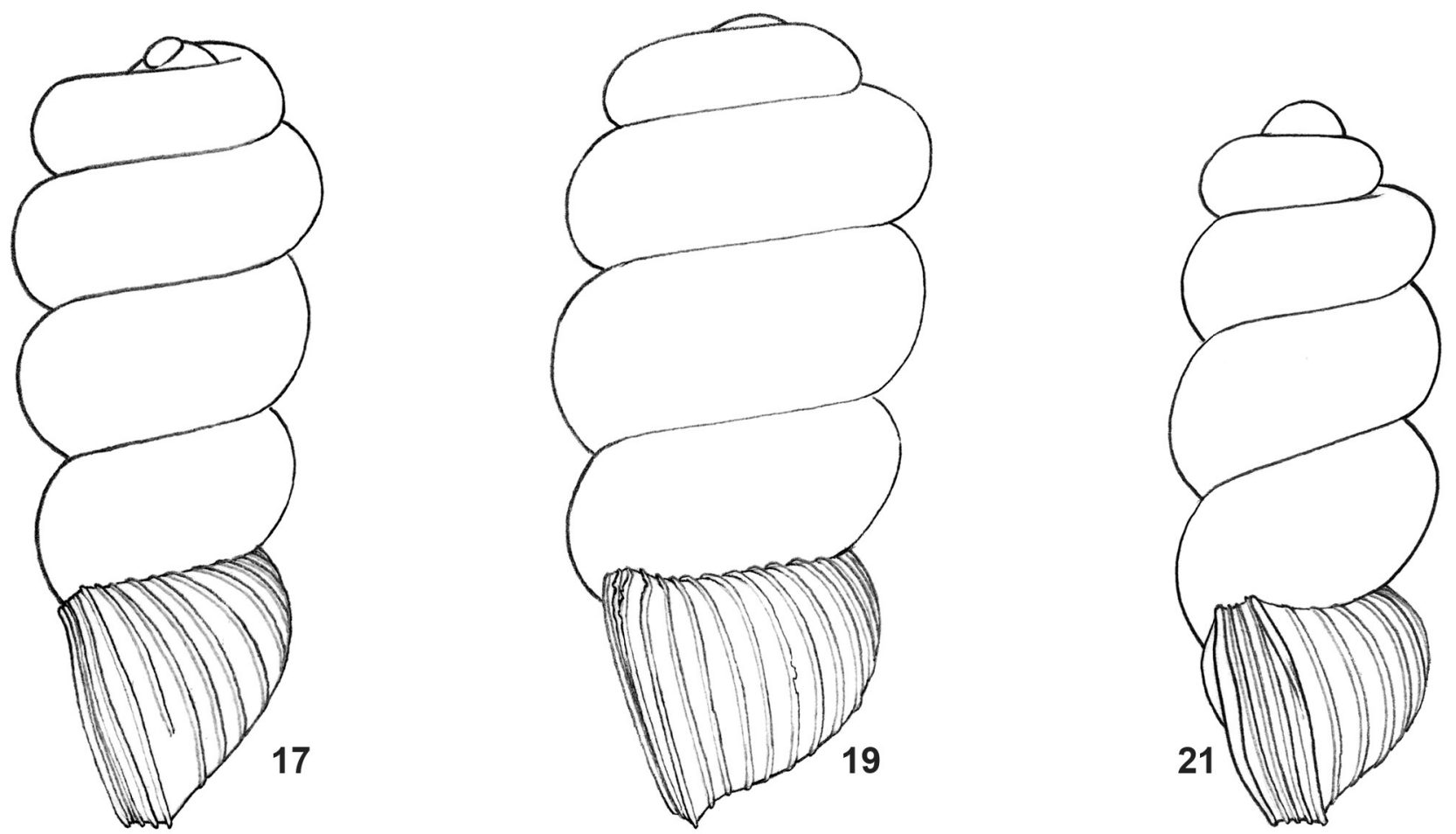

Figs 16-21. Notharinia stenobasis sp. n.: 16 - holotype, frontal view, shell height $2.1 \mathrm{~mm}, 17$ - same, right lateral view; Notharinia subduplex sp. n.: 18 - holotype, frontal view, shell height $2.2 \mathrm{~mm}, 19$ - same, right lateral view; Notharinia crassilabris Vermeulen, Phung et Truong: 20 - holotype, frontal view, shell height $2.1 \mathrm{~mm}, 21$ - same, right lateral view 
above the aperture, often somewhat more widely spaced, at least not congested, towards the peristome. Spiral striation absent. Aperture (shortly) attached to the penultimate whorl, approx. circular or slightly ovate; spire expanded towards the aperture. Peristome double, outer peristome slightly expanding beyond the inner on the upper palatal side, and often so in the basal corner; inner peristome slightly protruding from the outer, with one or several lamellae on the outer surface, approx. equally wide all around the aperture, somewhat thickened and somewhat reflexed. Umbilicus closed, covered by the body whorl, umbilical area shallowly concave.

Dimensions. Height $1.65-2.20 \mathrm{~mm}$; width (last whorl excluded) $0.75-0.90 \mathrm{~mm}$; height/width 2.20 2.69; number of whorls $47 / 8-57 / 8$; aperture height $0.50-0.65 \mathrm{~mm}$; width $0.50-0.60 \mathrm{~mm}$.

Ecology. Soil deposits in (moderately disturbed) semi-deciduous woodland on limestone bedrock.

Distribution. Cambodia, Kampot Province, Phnom La'Ang. Presumably a site endemic species.

Etymology. stenos (Gr) - narrow; basis (Gr) - basis

\section{Notharinia subduplex sp. $\mathrm{n}$.}

Figs 1 (yellow dots), 18-19

IUCN RED LIST Category, as Notharinia sp. nov. 'Khoe La': Critically Endangered Blab(i,ii,iii,v) + 2ab(i,ii,iii,v).

Examined material. Vietnam: Kien Giang Province, Kien Luong District: Nui Khoe La, north remnant, seaward side (V 14678/>10 shells); same, south remnant, landward side (holotype: NHMUK 20180559, paratypes: V 14679/10).

Cross diagnosis. Differs from N. attenuata in being wider, which is particularly useful to distinguish shells with an indistinctly double peristome.

Description. Shell minute, white. Spire cylindrical, not or hardly attenuated towards the basis, widely rounded to almost truncated towards the apex. Apex slightly oblique. Whorls moderately convex; suture impressed. Constriction absent. Sculpture. Radial ribs straight, distinct, rather low and thin, densely spaced, $12-14 / 0.5 \mathrm{~mm}$ on the first part of penultimate whorl; radial ribs on the body whorl (rather) densely spaced, 9-12 ribs/0.5 $\mathrm{mm}$ above the aperture, often more widely spaced, at least not congested, towards the peristome. Spiral striation absent. Aperture attached to the penultimate whorl, approx. circular; spire (slightly) expanded towards the aperture. Peristome double, sometimes indistinctly so; outer peristome slightly expanding beyond the inner on the upper palatal side, and often so in the basal corner; inner peristome slightly protruding from the outer, sometimes only so on the upper palatal side, with one or a few lamellae on the outer surface, ap- prox. equally wide all around the aperture or slightly wider in the basal corner, somewhat thickened and somewhat reflexed. Umbilicus closed, covered by the body whorl, umbilical area shallowly concave.

Dimensions. Height 2.00-2.30 mm; width (last whorl excluded) $0.95-1.05 \mathrm{~mm}$; height/width 2.11 2.42; number of whorls 5 1/4-5 5/8; aperture height 0.60-0.70 mm; width $0.50-0.70 \mathrm{~mm}$.

Ecology. Soil deposits in disturbed, semi-deciduous woodland and shrubby vegetation on limestone bedrock.

Distribution. Vietnam, Kien Giang Province, Kien Luong District, Nui Khoe La. Presumably a site endemic species.

Etymology. sub- (L, as prefix) - slightly, imperfectly, duplex (L) - double

\section{Group 5}

\section{Notharinia crassilabris Vermeulen, Phung et Truong, 2007}

Figs 1 (purple dots), 20-21

VERMEULEN et al. 2007: 86.

Examined material. Cambodia: Kampot Province, Kampong Trach area: Phnom Damrey, south hill (V 15684/1 shell); Kampot area: Phnom Sor Sear (V 15685/7). Vietnam: Kien Giang Province, Ha Tien Town area: Nui Da Dung (V 11444/>10); Nui Thach Dong (holotype: RMNH 108984, paratypes: V $11467 />10)$.

Cross diagnosis. Arinia (Notharinia) boucheti PállGergely, 2018 resembles N. crassilabris, and would fit within its range of variation. The difference lies in the distinctly concave outer peristome in A. boucheti. Description. Shell minute, white. Spire cylindrical, not or hardly attenuated towards the basis, towards the apex rounded to almost truncated. Apex slightly to moderately oblique. Whorls convex; one whorl half-way the spire sometimes moderately convex; suture impressed. Constriction absent. Sculpture. Radial ribs straight, distinct, rather high and thick, moderately spaced, $7-11 / 0.5 \mathrm{~mm}$ on the first part of penultimate whorl; radial ribs on the body whorl rather widely spaced, distinctly curved towards the suture, $6-8 / 0.5 \mathrm{~mm}$ above the aperture, even more widely spaced, at least not congested, towards the peristome. Spiral striation absent. Aperture attached to the penultimate whorl, approx. circular, sometimes somewhat angular in the basal corner; spire expanded towards the aperture. Peristome double; outer peristome (slightly) expanding beyond the inner, particularly on the upper palatal side, and in the basal corner; inner peristome distinctly protruding from the outer, with a few coarse, unevenly spaced lamellae to many fine lamellae on the outer surface, approx. equally 
wide all around the aperture or (slightly) wider in the basal corner, somewhat thickened and somewhat reflexed. Umbilicus closed, covered by the body whorl, umbilical area shallowly concave.

Dimensions. Height $1.40-2.30 \mathrm{~mm}$; width (last whorl excluded) $0.65-0.75 \mathrm{~mm}$; height/width $2.15-$ 2.93; number of whorls $41 / 2-57 / 8$; aperture height $0.45-0.65 \mathrm{~mm}$; width $0.45-0.65 \mathrm{~mm}$.

Ecology. Soil deposits in disturbed to degraded secondary woodland on limestone bedrock.

Distribution. Cambodia, Kampot Province. Vietnam, Kien Giang Province, Ha Tien Town area. Presumably endemic to the MDL.

\section{Notharinia whitteni sp. $\mathrm{n}$.}

Figs 1 (orange dots), 22-23

IUCN RED LIST Category: Not assessed, probably Critically Endangered Blab (i,ii,iii,v) + 2ab (i,ii,iii,v), because it has the same range as N. subduplex sp. n.

Examined material. Vietnam: Kien Giang Province, Kien Luong District: Nui Khoe La, north remnant, seaward side (holotype: NHMUK 20180560, paratypes: V 14681/>10 shells); same, south remnant, landward side (V 14680/6).

Cross diagnosis. Differs from $N$. crassilabris in its more densely spaced radial ribs: $12-18 / 0.5 \mathrm{~mm}$ on the first part of penultimate whorl and 9-14/0.5 mm above the aperture, versus $7-11 / 0.5 \mathrm{~mm}$ on the first part of penultimate whorl and $6-8 / 0.5 \mathrm{~mm}$ above the aperture.

Description. Shell minute, white. Spire cylindrical, not or hardly attenuated towards the basis, towards the apex (broadly) rounded. Apex slightly oblique. Whorls convex; one whorl half-way the spire sometimes moderately convex; suture impressed. Constriction absent. Sculpture. Radial ribs straight, distinct, rather high and thick, densely spaced, 12$18 / 0.5 \mathrm{~mm}$ on the first part of penultimate whorl; radial ribs on the body whorl (rather) densely spaced, somewhat curved towards the suture, 9-14/0.5 mm above the aperture, approx. equally densely arranged towards the peristome. Spiral striation absent. Aperture attached to the penultimate whorl, approx. circular to obtusely rectangular, sometimes somewhat angular in the basal corner; spire expanded towards the aperture. Peristome double; outer peristome (slightly) expanding beyond the inner, particularly on the upper palatal side, and in the basal corner; inner peristome distinctly protruding from the outer, with a few coarse, unevenly spaced lamellae to many fine lamellae on the outer surface, approx. equally wide all around the aperture or slightly wider in the basal corner, somewhat thickened and somewhat reflexed. Umbilicus closed, covered by the body whorl, umbilical area shallowly concave.

Dimensions. Height $1.40-1.75 \mathrm{~mm}$; width (last whorl excluded) $0.65-0.75 \mathrm{~mm}$; height/width 2.07 2.38; number of whorls 4 7/8-5 1/8; aperture height $0.50-0.60 \mathrm{~mm}$; width $0.45-0.60 \mathrm{~mm}$.

Ecology. Soil deposits in disturbed, semi-deciduous woodland and shrubby vegetation on limestone bedrock.

Distribution. Vietnam, Kien Giang Province, Kien Luong Dist., Nui Khoe La. Presumably a site endemic species.

Etymology. Named in commemoration of Tony Whitten (1953-2017; see https://www.theguardian.
22

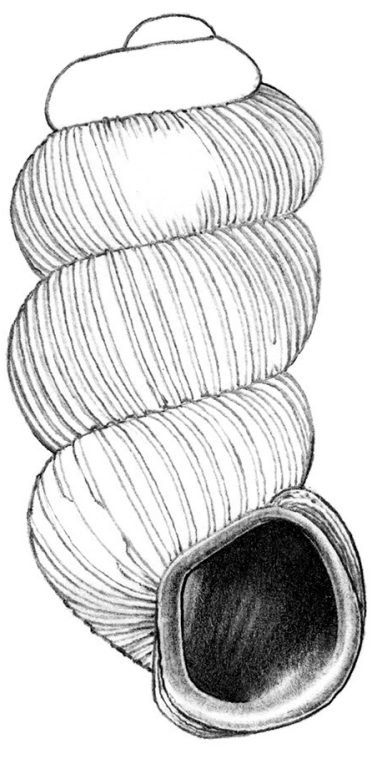

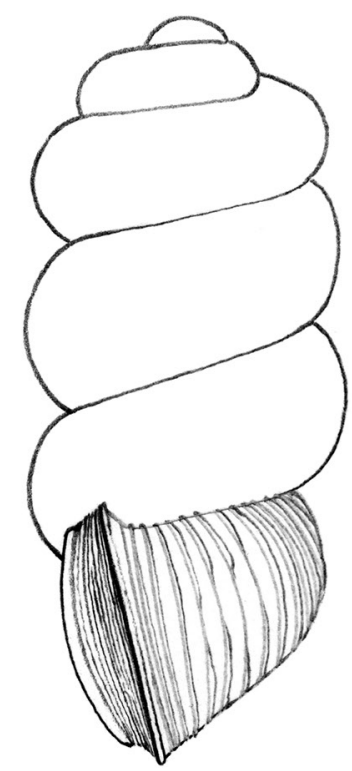

23

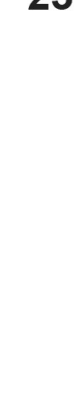


com/environment/2017/dec/08/tony-whitten-obituary) who, after a life dedicated to biodiversity conservation, died tragically in an accident.

\section{Genus Plectostoma H. Adams, 1865}

\section{Plectostoma lavillei (Dautzenberg et Fischer, 1905)}

Diplommatina lavillei DAUTZENBERG \& FISCHER (1905: 442).

Plectostoma haplohelix VermeUlen, LUU, KeUM \& ANKER (2019: 19), new synonym

Note. We have compared the type material of Plectostoma haplohelix with images of the type of Diplommatina lavillei, provided by the Paris Museum

\section{REFERENCES}

ADAMS H., ADAMS A. 1854-1858. The genera of recent Mollusca 2. John van Voorst, London.

DAutzenberg P., Fischer H. 1905. Liste des Mollusques récoltés par M.Mansuy en Indo-Chine et au Yunnan et description d'espèces nouvelles, II. Journal de Conchyliologie, Paris 53: 343-471.

EGOROV R. 2013. A review of the genera of the terrestrial Pectinibranch molluscs (synopsis mainly based on published data). Part III. Littoriniformes. Liareidae, Pupinidae, Diplommatinidae, Alycaeidae, Cochlostomidae. Treasure of Russian shells. Supplement 3. Colus-Doverie Ltd. Press, Moscow.

IUCN RED LIST - The IUCN (International Union of Conservation of Nature) Red List of Threatened Species, available at https://www.iucnredlist.org/.

MAASSEN W. J. M. 2008. A new species of Notharinia Vermeulen, Phung \& Truong, 2007 from Peninsular Malaysia (Mollusca, Caenogastropoda, Pupinidae). Zoologische Mededelingen 82: 101-104.

MARZUKI M. E. BIN, FOON J. K. 2016. A new land snail, Arinia (Notharinia) micro (Caenogastropoda: Cyclophoroidea: Diplommatinidae), from a limestone karst in Perak, Peninsular Malaysia. Raffles Bulletin of Zoology 64: 313-318.
(MNHN). We found no significant differences and concluded that the two names referred to the same species. Both types originate from the same limestone hill.

\section{ACKNOWLEDGEMENTS}

We acknowledge the support of the Ministry of Environment of Cambodia and the Kieng Giang provincial government of Vietnam. We also acknowledge organisations that funded the surveys, namely Chip Mong INSEE Cement Corporation (CMIC), and Siam City Cement (Vietnam) Limited (SCCVN, previously Lafarge-Holcim Vietnam, and Holcim Vietnam Ltd). The publication of this paper was supported by FFI with funding from Dr JOHN MEERS.

PÁll-Gergely B., Hunyadi A. 2018. Four new cyclophoroid species from Thailand and Laos (Gastropoda: Caenogastropoda: Alycaeidae, Diplommatinidae, Pupinidae). Zoosystema 40: 59-66. https://doi. org/10.5252/zoosystema2018v40a3

VERMEULEN J. J. 1996. Notes on the nonmarine molluscs of the island of Borneo 8. The genus Arinia; additions to the genera Diplommatina and Opisthostoma (Gastropoda Prosobranchia: Diplommatinidae). Basteria 60: 87-138.

Vermeulen J. J., Phung C. L., Truong Q. T. 2007. New species of terrestrial molluscs (Caenogastropoda, Pupinidae \& Pulmonata: Vertiginidae) of the Hon Chong - Ha Tien limestone hills, southern Vietnam. Basteria 71: 81-92.

Vermeulen J. J., LuU H. T., Keum T., AnKer K. 2019. New species of land snails (Mollusca: Gastropoda: Caenogastropoda and Pulmonata) of the Mekong Delta Limestone Hills (Cambodia, Vietnam). Folia Malacologica 27: 7-41. https://doi.org/10.12657/folmal.027.001

Received: May 11th, 2019

Revised: June 10th/15th, 2019

Accepted: June 16th, 2019

Published on-line: August 1st, 2019 